\title{
Role of Conservation Tillage as Climate Change Mitigation
}

\author{
Ketema Niguse Baye* Anteneh Agezew Melash Amare Assefa Bogale \\ Debark University, College of Agriculture and Environmental Sciences, Department of Plant Sciences \\ PO. Box 90, Debark, Ethiopia
}

\begin{abstract}
There is an urgent need to match food production with increasing world population through identification of sustainable land management strategies. However, the struggle to achieve food security should be carried out keeping in mind the soil where the crops are grown and the environment in which the living things survive. Conservation Tillage (CT), practicing agriculture in such a way so as to cause minimum damage to the environment, is being advocated at a large scale world-wide, and is thought to take care of the soil health, plant growth and the environment. This paper aims to review the work done on conservation tillage in different agroecological regions so as to understand its impact from the perspectives of the soil, the crop and the environment. Research reports have identified several benefits of conservation tillage over conventional tillage (CT) with respect to soil physical, chemical and biological properties as well as crop yields and reduction in carbon dioxide emission from soil into the atmosphere. Processes of climate change mitigation and adaptation found zero tillage (ZT) to be the most environmental friendly among different tillage techniques.
\end{abstract}

Keywords: Conservation Tillage, Sustainable Soil management, Climate Change

DOI: $10.7176 / \mathrm{CER} / 11-1-03$

\section{INTRODUCTION}

Nowadays the agriculture becomes one of the most important drivers of climate change as a temperature and greenhouse gas emission, which contribute about $13-15 \%$ of global greenhouse gas emissions (Lybbert and Sumner, 2010). The conventional soil tillage based on using plough contributes on higher soil carbon losses through $\mathrm{CO}_{2}$ emissions (Reicosky a Saxton, 2007). In the other word, this sector is critical that susceptible to the changing climate and simultaneously plays a vital role in the reduction of greenhouse gas production which attributes the climate change impact. This means that the agricultural sector can change its role from $\mathrm{CO}_{2}$ producer into $\mathrm{CO}_{2}$ absorber (Goh, 2004; Reicosky, 2007).

\subsection{Agricultural Contribution to emissions}

The agriculture sector accounts for about $13 \%$ of global anthropogenic greenhouse gas emissions, i.e. between 5 and $6 \mathrm{Giga}$ tones (Gt) of $\mathrm{CO}_{2}$ equivalents $\left(\mathrm{CO}_{2} \mathrm{e}\right)$ per year (Barker et al., 2007). Methane is emitted largely from livestock (fermentation in digestion), rice production and manure handling. Carbon dioxide also released mainly from microbial decay of plant litter and soil organic matter, as well as from burning of plant residues (Smith, 2004). The agricultural inputs like Urea and ammonium nitrate $\left(\mathrm{NH}_{4} \mathrm{NO}_{3}\right)$ are widely used fertilizers. Ammonium nitrate was beneficial in reducing the volatility of $\mathrm{NH}_{3}$ and the emission of $\mathrm{N}_{2} \mathrm{O}$ (Mc Taggart et al., 1994).Most cropped soils emit $\mathrm{N}_{2} \mathrm{O}$ at $1.5 \%$ of their nitrogen input (Paustian et al., 2004). Decreasing $\mathrm{N}$ inputs decrease $\mathrm{N}_{2} \mathrm{O}$ emissions. Only half of the $\mathrm{N}$ input is captured in crop biomass, and the remainder is lost from the system by leaching and gaseous losses. Any practice that tightens the coupling between soil nitrogen release and crop growth will enhance nutrient use efficiency and diminish the need for exogenous $\mathrm{N}$ and decrease $\mathrm{N}_{2} \mathrm{O}$ flux. Any practice that conserves $\mathrm{N}$ within the system can also reduce $\mathrm{N}_{2} \mathrm{O}$ emissions.

\subsection{Agricultural Contribution to Mitigation}

The agriculture sector also contributes significantly to GHG mitigation by acting as GHG sink for $10 \%$ of emissions. Agriculture creates a reduction in global GHG emissions by approximately $32 \%$ by absorbing $\mathrm{CO}_{2}$ emissions, $42 \%$ by carbon offsets through biofuel production, $15 \%$ by reducing methane emissions and $10 \%$ from reducing emissions of $\mathrm{N}_{2} \mathrm{O}$ (IPCC, 2007). Mitigation could be accomplished through intensification and extensification of agriculture. Intensification may increase emission of GHGs per hectare due to high input of fertilizers, extensive mechanized tilling of soil, and heavy use of pesticides and use of inorganic fertilizers. However, it could reduce total land requirement and total agricultural emissions, i.e., a reduced carbon footprint per $\mathrm{kg}$ of product. Extensification creates a reduction in emission per hectare due to less use of fertilizers, labor, capital and less mechanization but total land requirement may increase slightly. Emission strategies are generally grouped as: (1) enhancement of sinks for $\mathrm{CO}_{2}$ sequestration (2) emission reduction from agriculture, and (3) avoidance of emissions via replacement products or land use change prevention. Schneider and Kumar (2008) interpreted sinks as reversals of past agricultural emissions which include carbon sequestration in soils and the increase in biomass productivity by altering management and land use changes. The potential emission reductions from agriculture include lower $\mathrm{CH}_{4}$ emissions from rice fields, ruminant's animals and manure; lower $\mathrm{N}_{2} \mathrm{O}$ emissions from changes in fertilizer use and manure management and lower $\mathrm{CO}_{2}$ emission by reduced fossil 
fuel consumption in agriculture. The avoidance of emissions by using replacement products includes: prevention of deforestation, substitution of fossil fuels by biomass-based energy (e.g., ethanol, biodiesel) and use of biomaterial to replace GHG emitting products (e.g., bamboo in place of aluminum).

However, these strategies should be applied with consideration of local conditions. If agricultural land is used for energy crop plantations, wetland restoration, and a forestation, it will lead to the reduction in land for crop production and food security. Wetland restoration may sequester a large amount of $\mathrm{CO}_{2}$, but it will also contribute to higher methane emissions. Energy crops act as beneficial carbon offsets, but they can also lead to undesirable nitrous oxide emissions (Crutzen et al., 2008). Use of excess $\mathrm{N}$-fertilizer required for the production of an energy crop can result in more emissions of nitrous oxide. This may contribute more to the global warming by emitting $\mathrm{N}_{2} \mathrm{O}$ than cooling by saving on fossil fuels. However, crops with less nitrogen demand such as grasses and woody species may have positive climate impacts i.e., net reduction in equivalent GHG emissions.

In general, there are four principal issues of global concern with regards to agricultural production. The first is related to the finite extent of land resources, second to the impact of agricultural activities on environmental quality in general, but the 'greenhouse' effect in particular, third to the role of residue management and conservation tillage (CT) in carbon sequestration, and fourth to restoration of degraded soils by enhancing soil resilience and quality. An important strategy is to restore degraded lands, and intensify agricultural production while mitigating the greenhouse effect is the tillage management which is conservation tillage.

Crops cannot be produced without disturbing the soil in some way. In this case tillage systems may be separated into two types (Kotler, 2003), conservation tillage and conventional tillage. Conservation tillage covers a range of practices which conserve soil moisture and reduce soil erosion by maintaining a minimum of $30 \%$ of the soil surface covered by residue after drilling. Generally, conservation tillage includes a shallow working depth without soil inversion, i.e. no tillage or reduced or shallow tillage with tine or discs. Shallow ploughing, to no more than $10 \mathrm{~cm}$, should be included in conservation tillage because burial of crop residues is usually incomplete. Conventional systems of tillage leave less than $30 \%$ of crop residues and often none, on the soil surface after crop establishment.

Conventional tillage is invariably deeper $(20-35 \mathrm{~cm})$ with inversion of the soil by mould board plough, disc plough or spading machine. Conservation tillage leaves an organic mulch at the soil surface, which reduces runoff, increases the surface soil organic matter (SOM) promoting greater aggregate stability which restricts soil erosion (Franzluebbers, 2002). Other beneficial aspects of conservation tillage are preservation of soil moisture and increase of soil biodiversity (Holland, 2004). Conservation tillage also, ideally, decreases water pollution (via decreasing soil erosion) and saves fossil fuel energy and thus decreases $\mathrm{CO}_{2}$ emissions, compared to conventional tillage systems. Because soil organic matter tends to increase under conservation tillage, as compared to conventional plowing, the soils are also more effective at storing carbon.

In general tillage systems influence physical, chemical, and biological properties of soil and have a major impact on soil productivity and sustainability. Conventional tillage practices may adversely affect long-term soil productivity due to erosion and loss of organic matter in soils. Sustainable soil management can be practiced through conservation tillage (including no-tillage), high crop residue return, and crop rotation (Crutzen et al., 2008).

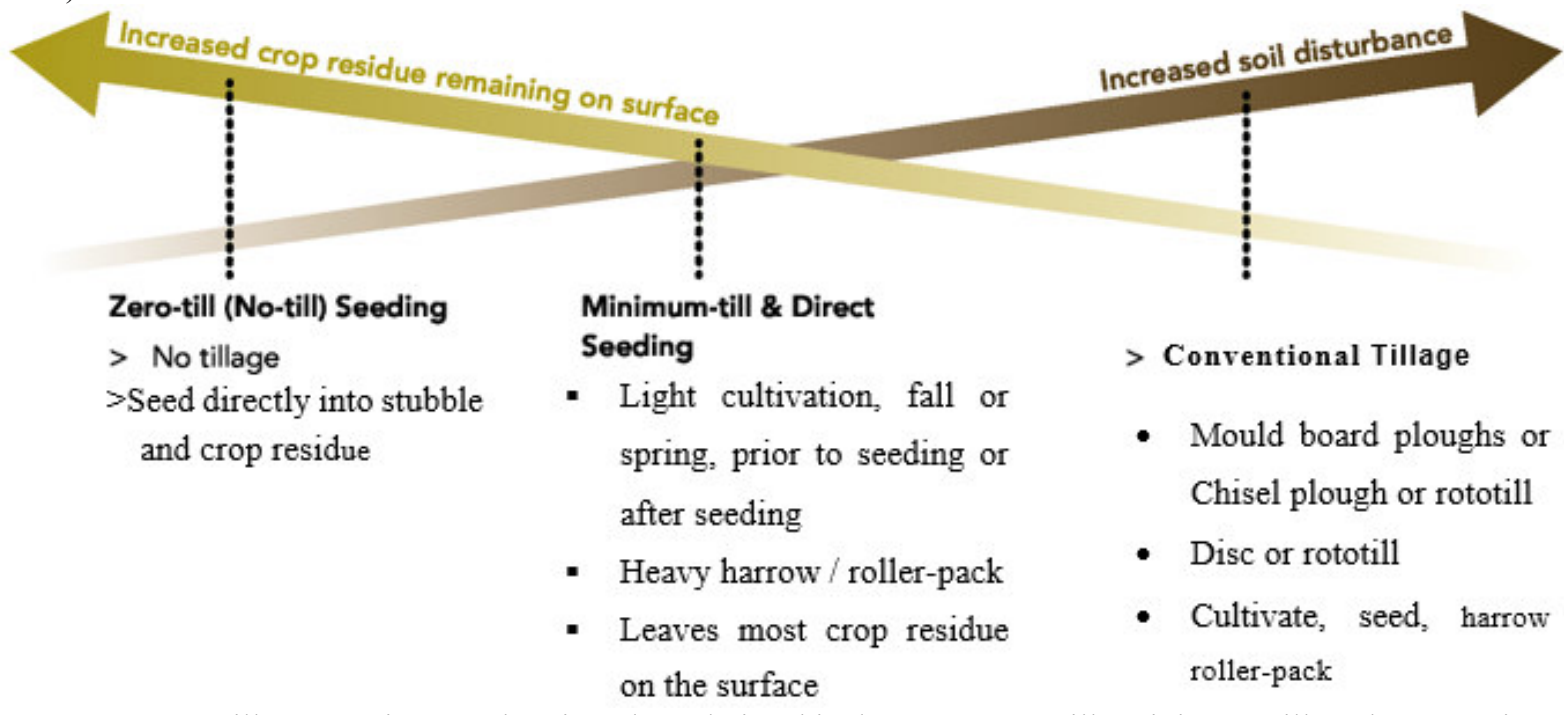

Figure.1. crop tillage continuum showing the relationship between zero-till, minimum till and conventional tillage system and associated level of soil disturbance and crop residue left on the soil surface (Allen 2013). 


\subsection{Conservation Tillage System}

Conservation tillage (CT) is a practical tool to use crop residues for soil and water conservation and of soil quality enhancement. Understanding the role of CT is important to develop strategies and identify policies for sustainable use of soil and water resources, for mitigating the greenhouse effect and improving environmental quality.

Conservation tillage was defined in 1984 by the U.S. Soil Conservation Service (currently the USDA Natural Resources Conservation Service) as "any tillage system that maintains at least 30\% of the soil surface covered by residue after planting primarily where the objective is to reduce water erosion" (MWPS 2000; Owens 2001). When wind erosion is a concern, the term refers to tillage systems that maintain at least 1,000 pounds per acre $(1,120 \mathrm{~kg} / \mathrm{ha})$ of flat "small-grain residue-equivalents" (MWPS 2000; Owens 2001; ASAE 2005) on the soil surface during critical erosion periods. The term "conservation tillage" broadly encompasses tillage practices that "reduce the volume of soil disturbed (Reicosky 2002); preserve rather than incorporate surface residues; and "result in the broad protection of soil resources while crops are grown" (Allmaras and Dowdy 1985).

Conservation tillage has thus been described as a collective umbrella term that denotes practices that have a conservation goal of some nature (Reicosky 2002). Many different planters, implements, and general approaches have been used to achieve this goal. Because of the importance of surface residues to this early definition of CT, the USDA NRCS now uses the term "crop residue management" (CRM) rather than "conservation tillage" in their inventories of conservation practices. The conservation tillage practices have a range of tillage practice which is describe as follow:

\subsubsection{Types of Conservation Tillage}

Conservation tillage systems include a variety of techniques, mostly non-inversion, which aim to conserves oil moisture and reduce soil erosion by leaving more than one-third of the soil surface covered by crop residues. Conservation tillage is generally considered as an important component of sustainable agriculture and The CTIC identified the following five types of conservation tillage systems:
i. no-tillage (slot planting),
ii. Mulch tillage,
iii. Strip or zonal tillage,
iv. Ridge till and
v. $\quad$ Reduced or minimum tillage.

\subsubsection{No-till or Zero-till}

The CTIC defines no-till as a system in which the soil is left undisturbed from harvest to planting except for nutrient injection. Tillage is essentially eliminated with a no-till system. The only tillage that is used is the soil disturbance in a narrow slot created by coulters or seed openers (Conservation Tillage Systems and Management, 2000). No-till planting is well suited to many soils but limited application in poorly drained soils. Residue, when uniformly spread, increases water infiltration and reduces soil moisture evaporation. No-till has carbon sequestration potential through storage of soil organic matter in the soil of crop fields. By eliminating tillage, crop residues decompose where they lie, and growing crops field carbon loss can be slowed and eventually reversed. In general Weed control is generally accomplished with herbicides. "Direct seeding" is a synonym for "no-tillage" that is commonly used in small grain production systems.

\subsubsection{Ridge-Tillage}

In ridge-tillage, the soil is also generally undisturbed from harvest to planting except for fertilizer injection. Crops are seeded and grown on ridges or shallow beds that have been formed or built during the prior growing season, generally during cultivation using implements fitted with sweeps, hilling disks, and furrowing wings (MWSFS 2000).

\subsubsection{Mulch-Tillage}

Mulch-tillage, the fourth major CT category used in CTIC and NRCS tillage system acreage surveys, includes any CT system other than no-tillage, strip-tillage, or ridge-tillage that preserves 30 percent or more surface residues (MWFS 2000). Mulch-tillage uses conventional broadcast tillage implements such as disks, chisel plows, rod weeders, or cultivators, but with limited passes across a field so as to maintain plant residue on the soil surface year-round (ASAE 2005). This was probably the earliest approach to CT, and it dates back to 1930 when the first chisel plow was used.

\subsubsection{Strip-Tillage}

The concept of strip or zonal tillage is described by Lal $(1973,1983)$. The seedbed is divided into a seedling zone and a soil management zone. The seedling zone (5 to $10 \mathrm{~cm}$ wide) is mechanically tilled to optimize the soil and micro-climate environment for germination and seedling establishment. The inter-row zone is left undisturbed and protected by mulch. Strip tillage can also be achieved by chiseling in the row zone to assist water infiltration and root proliferation. With strip-tillage, the seed row is tilled prior to planting to allow residue removal, soil drying and warming, and in some cases sub-soiling. 


\section{Role of Conservation Tillage on Sustainable Soil Management}

\subsection{Conservation tillage and soil properties}

Tillage impact is noticeable on soil physical, chemical and biological properties though in different magnitudes. Tillage impact also includes the effect on the soil environment in the form of runoff and soil erosion (Bhatt \& Khera, 2006). Therefore, one of the basic and important components of agricultural production technology is soil tillage. Various forms of tillage are practiced throughout the world, ranging from the use of simple stick or jab to the sophisticated Para-plough. However, tillage affects soil physical, chemical and biological properties. Research results have been widely reported on the effects of tillage on soil aggregation, temperature, water infiltration and retention as the main physical parameters affected. The magnitude of the changes depends on soil types as well as soil composition. Changes in chemical properties are dependent mainly on the organic matter content of the soils. Tillage affects aeration and thus the rate of organic matter decomposition. Biological activities in the soil are vital to soil productivity through the activities of earthworms, termites and the many other living creatures in the soil. These influence water infiltration rates by their burrowing in the soil and their mucilage promotes soil aggregation.

Tillage effects on soils are closely related to the management of crop residues in and on the surface of the soil. Unger et al. (1991) point out that the two practices with major impact on soil conservation are crop residue management and tillage. The traditional ploughing-in of crop residues is now giving way to surface soil residue management, which is more related to soil and water conservation, particularly in the semi-arid tropics.

\subsubsection{Soil physical properties}

Effects of conservation tillage on soil properties vary, and these variations depend on the particular system chosen. No-till (NT) systems, which maintain high surface soil coverage, have resulted in significant change in soil properties, especially in the upper few centimeters (Anikwe and Ubochi, 2007). According to Lal (1997), soil physical properties are generally more favorable with no-till than tillage-based systems. Many researchers have found that NT significantly improved saturated and unsaturated hydraulic conductivity owing to either continuity of pores (Benjamin, 1993) or flow of water through very few large pores (Allmaras, et al., 1977).

It has been reported that well-drained soils, light to medium in texture with low humus content, respond best to conservation tillage (Butorac, 1994) especially to no-tillage. According to Lal, et al. (2007) NT technologies are very effective in reducing soil and crop residue disturbance, moderating soil evaporation and minimizing erosion losses. More stable aggregates in the upper surface of soil have been associated with no-till soils than tilled soils and this correspondingly results in high total porosity under NT plots. Jacobs et al. (2009) found that minimum tillage (MT), compared with CT, did not only improve aggregate stability but also increased the concentrations of SOC and N within the aggregates in the upper 5-8 cm soil depth after 37-40 years of tillage treatments. In terms of water conservation, NT has been found to be more effective in humid and subhumid tropics. Kargas et al. (2012) observed that untilled plots retain more water than tilled plots. In comparison with conventional ploughing, Pagliai et al. (2004) reported that minimum tillage improved the soil pore system by increasing the storage pores $(0.5-50 \mathrm{~mm})$ and the amount of the elongated transmission pores $(50-500 \mathrm{~mm})$. They related the higher micro-porosity in minimum tillage soils to an increase of water content in soil and consequently, to an increase of available water for plants. Higher water holding capacity or moisture content has been found in the topsoil $(0-10 \mathrm{~cm})$ under NT than after ploughing (McVay et al., 2006). Therefore, to improve soil water storage and increase water use efficiency (WUE) most researchers have proposed replacement of traditional tillage with conservation tillage (Freebairn and Rattray, 2007). Water use efficiency has also been reported to be greater in soils under reduced tillage (McVay et al., 2006) and NT (Li, Huang, \& Zhang, 2005) systems as compared with CT. Su et al. (2007) found that the soil water storage quantity using ZT was $25 \%$ higher than CT during a six year study while WUE was significantly higher in ZT than CT and RT. On a sandy Alfisol, Busari and Salako (2012) observed higher unsaturated water flow parameters and infiltration rate under CT and MT than ZT.

In general soil management has a direct impact on crop yield levels, food quality and safety, the environment and climate change, and it helps break down or "degrade" agriculture chemicals or other potential pollutants; it also serves to hold carbon, and is the medium through which water, nutrients and microbes interactit's a buffer between production inputs and, the environment.

\subsubsection{Soil Compaction}

The reduction in soil compaction under reduced tillage is mainly due to less traffic, additional crop residues at the surface (Jastrow et al., 2007) and increased biological activity provided by soil macro and micro fauna (Simmons and Coleman, 2008). A number of studies have indicated that continuous conservation tillage practices over the long term reduce bulk density of soil (Li et al., 2011). Lal et al. (1994) found that after 28 years of maize and soybean, the lowest bulk density soil was in no-till soils. In another study a continuous no-till system for 43 years significantly decreased bulk density at the surface $(0-15 \mathrm{~cm})$ of a silt loam soil with little effect on the subsurface layer $(15-30 \mathrm{~cm}$ ) (Ussiri et al., 2009); the surface decrease being explained by the changes in soil pore structure, carbon content and biological activity with greater impact mainly at the surface. 
The lower bulk density under conservation tillage may be beneficial for easier root penetration into deeper layers and thereby increasing the crop derived carbon input to the soil.

This is specifically important in the case of deep rooted plants, since photosynthesis, which are translocated into the below ground portions are added to soil through rhizo-deposition (Baker et al., 2007). The decreased soil bulk density can aid in the downward movement of surface accumulated carbon (Luo et al., 2010), by preferential accumulation of plant residues moving in the soluble fraction (Angers and Eriksen-Hamel, 2008). Blanco-Canqui et al. (2011) also found a moderate negative correlation between bulk density and soil organic carbon throughout a $1 \mathrm{~m}$ soil depth under no-till. However, there are reports stating continuous conservation tillage might also lead to increased soil strength and soil density (Hernanz et al., 2009). Hill (1990) noticed increased bulk density and soil strength in the no-till treatments over an 11-12 year no-tillage experiment under continuous maize cultivation. Similar investigation by Lopez-Fando and Pardo (2011) found significantly higher surface bulk density under no-till soil than conventionally tilled soil over 20 years of experimentation in central Spain with a crop sequence of Check pea (Cicer arietinum L)/ barley (Hordeum vulgare L.). The reasons attributed to increased bulk density under conservation tillage systems are increased settling of soil due to lack of cultivation (Hermle et al., 2008) which can lead to soil consolidation (Peigne et al., 2007). However, the enhanced bulk density might not prevent the growth of roots if pore continuity is enhanced by creation of more biological macro-pores (Peigne et al., 2007).

\subsubsection{Soil chemical properties}

Soil chemical properties that are usually affected by tillage systems are $\mathrm{pH}, \mathrm{CEC}$, exchangeable cations and soil total nitrogen. According to Lal (1997) soil chemical properties of the surface layer are generally more favorable under the no-till method than under the tilled soil. Annual no-tillage, implying yearly practice of no-till system over a long period of time, is beneficial to maintenance and enhancement of the structure and chemical properties of the soil, most especially the SOC content. Rasmussen (1999) and During, Thorsten, and Stefan (2002) observed that with annual no-tillage, plant residues left on the soil surface increase the organic matter in the topsoil. Similarly, Ismail et al., (1994) and Lal (1997) reported a significantly higher SOC in soil with NT compared to un-tilled soil. A reduced total N loss was also observed under NT compared to CT by Dalal (1992). Higher mineralization and/or leaching rate could be implicated for reduction in organic $\mathrm{C}$ and total $\mathrm{N}$ under tilled plot due to soil structure deterioration following tillage.

Tillage technique is often shown to have no effect on soil $\mathrm{pH}$ (Rasmussen, 1999), though soil $\mathrm{pH}$ has been reported to be lower in no-till systems compared to CT (Rahman et al., 2008). The lower pH in ZT was attributed to accumulation of organic matter in the upper few centimeters under ZT soil (Rhoton, 2000) causing increases in the concentration of electrolytes and reduction in $\mathrm{pH}$ (Rahman et al., 2008). Conversely, Cookson, et al., (2008) found that surface soil $\mathrm{pH}$ decreased with increasing tillage disturbance and Lal (1997) reported a significantly higher soil $\mathrm{pH}$ in NT plots compared to those in tilled plots. Therefore, tillage may not directly affect soil $\mathrm{pH}$ but its effects on $\mathrm{pH}$ will depend on the prevailing climatic condition, soil type and management factors. Ismail et al. (1994) and Rahman et al. (2008) reported that exchangeable $\mathrm{Ca}, \mathrm{Mg}$, and $\mathrm{K}$, were significantly higher in the surface soil under NT compared to the ploughed soil.

According to Ali, et al., (2006), the lowest values of soil OM, N, P, K, Ca and Mg were recorded in conventional till plots and it could be due to the inversion of top soil during ploughing which shifts less fertile subsoil to the surface in addition to possible leaching, Busari and Salako (2013) observed that ZT soil had a significantly higher $\mathrm{pH}$ at the end of the first year after tillage but the $\mathrm{pH}$ became significantly lower compared with the CT soil at the end of the second year after tillage. However, the soil organic C (SOC) and the effective cation exchange capacity (ECEC) were significantly higher at the end of the two years of study under ZT than under CT (Table 2). The study however, revealed that minimum tillage (MT) resulted in significantly higher $\mathrm{pH}$ and SOC than CT at the end of each of the two years of the study suggesting that less soil disturbance is beneficial to soil chemical quality improvement.

Table1. Effect of tillage on soil chemical properties after maize harvest (Busari and Salako 2013).

\begin{tabular}{|c|c|c|c|c|c|c|c|c|c|c|}
\hline Year & 2008 & & & & & 2009 & & & & \\
\hline Tillage & $\begin{array}{c}\mathrm{pH} \\
\left(\mathrm{H}_{2} \mathrm{O}\right)\end{array}$ & $\begin{array}{c}\mathrm{OC} \\
\left(\mathrm{gkg}^{-1}\right)\end{array}$ & $\begin{array}{c}\mathrm{TN} \\
\left(\mathrm{g} \mathrm{kg}^{1}\right)\end{array}$ & $\begin{array}{l}\text { Avail. P } \\
\left(\mathrm{mg} \mathrm{kg-}^{-1}\right)\end{array}$ & $\begin{array}{c}\text { ECEC } \\
\left(\mathrm{cmol} \mathrm{kg-}^{1}\right)\end{array}$ & $\begin{array}{c}\mathrm{pH} \\
\left(\mathrm{H}_{2} \mathrm{O}\right)\end{array}$ & $\begin{array}{c}\mathrm{OC} \\
\left(\mathrm{g} \mathrm{kg}^{-1}\right)\end{array}$ & $\begin{array}{c}\mathrm{TN} \\
\left(\mathrm{g} \mathrm{kg}^{1}{ }^{1}\right)\end{array}$ & $\begin{array}{c}\text { Avail. P } \\
\left(\mathrm{mg} \mathrm{kg} \sim^{1}\right)\end{array}$ & $\begin{array}{c}\text { ECEC } \\
\left(\mathrm{cmol} \mathrm{kg-}^{1}\right)\end{array}$ \\
\hline $\mathrm{CT}$ & 6.0 & 16.50 & 1.38 & 26.64 & 6.31 & 6.69 & 2.79 & 0.32 & 65.59 & 8.05 \\
\hline MT & 6.2 & 19.80 & 1.52 & 24.33 & 6.24 & 6.79 & 4.59 & 0.55 & 40.47 & 8.51 \\
\hline ZT & 6.1 & 21.20 & 1.58 & 33.28 & 7.36 & 6.64 & 5.00 & 0.53 & 61.13 & 9.39 \\
\hline $\begin{array}{l}\text { LSD } \\
(\operatorname{Pr} 0.05)\end{array}$ & 0.05 & 2.20 & ns & 7.13 & 0.49 & 0.04 & 0.44 & 0.08 & 13.25 & 0.79 \\
\hline
\end{tabular}

OC1/4organic carbon; TN1/4total nitrogen; Available P1/4available phosphorus, ECEC1/4effective Cation exchange capacity; ZT1/4zero tillage; MT1/4minimum tillage; $\mathrm{CT}^{1} 1 / 4$ conventional tillage; $\mathrm{LSD}=$ least significant difference; ns $1 / 4$ not significant. 


\subsubsection{Soil biological properties}

The soil biological property most affected by tillage is SOC content (Doran, 1980). The soil organic matter content influences to a large extent the activities of soil organism which in turn influence the SOC dynamics. Earthworms which are a major component of the soil macro-fauna are important in soil fertility dynamics as their burrowing activities aid in improvement of soil aeration and water infiltration. The fact that the populations of earthworms are affected by tillage practices has been documented in a ploughless tillage review by Rasmussen (1999). A six-year study by Andersen (1987) revealed a significantly higher earthworm population under no-till soil than under ploughed soil. Kemper et al. (1987) reported that less intense tillage increased the activities of surface-feeding earthworms. Due to disruption of fungi mycelia by tillage technique, Cookson et al. (2008) observed a decreased fungal biomass and increased bacterial biomass with increasing tillage disturbance. They also reported alteration in the composition and substrate utilization of the microbial community with distinct substrate utilization in no-till soil.

Table. 2. A summary of a comparison of traditional tillage, and conservation tillage (CT)

\begin{tabular}{|c|c|c|}
\hline Issues & Traditional Tillage (TT) & Conservation Tillage (CT) \\
\hline Practice & disturbs the soil and leaves a bare surface & $\begin{array}{l}\text { reduces the soil disturbance } \\
\text { in TT and keeps the soil covered }\end{array}$ \\
\hline Erosion & wind and soil erosion: maximum & $\begin{array}{l}\text { wind and soil erosion: } \\
\text { reduced significantly }\end{array}$ \\
\hline Soil physical health & the lowest of the three & significantly improved \\
\hline Compaction & $\begin{array}{l}\text { used to reduce compaction and can also induce it by } \\
\text { destroying biological pores }\end{array}$ & $\begin{array}{l}\text { reduced tillage is used to reduce } \\
\text { compaction }\end{array}$ \\
\hline Soil biological health & the lowest of the three owing to frequent disturbance & $\begin{array}{l}\text { Moderately better soil biological } \\
\text { health }\end{array}$ \\
\hline Water infiltration & lowest after soil pores clogged & good water infiltration \\
\hline Soil organic matter & $\begin{array}{l}\text { oxidizes soil organic matter and causes its loss soil } \\
\text { organic build-up possible in the surface layers }\end{array}$ & $\begin{array}{l}\text { soil organic build-up possible in } \\
\text { the surface layers }\end{array}$ \\
\hline Soil biological health & $\begin{array}{l}\text { the lowest of the three owing } \\
\text { to frequent disturbance }\end{array}$ & $\begin{array}{l}\text { moderately better soil } \\
\text { biological health }\end{array}$ \\
\hline Soil temperature & surface soil temperature: more variable & $\begin{array}{l}\text { surface soil temperature: } \\
\text { intermediate in variability }\end{array}$ \\
\hline Diesel use and costs & diesel use: high & diesel use: intermediate \\
\hline Timeliness & operations can be delayed & $\begin{array}{l}\text { intermediate } \\
\text { operations }\end{array}$ \\
\hline Production costs & highest costs & intermediate costs \\
\hline Yield & can be lower where planting delayed & yields same as TT \\
\hline
\end{tabular}

Sources: Hobbs et al., (2007)

\subsection{Impact of Conservation Tillage on Nutrient Losses}

Conservation tillage systems impact both soil erosion and water infiltration, which in turn can affect the runoff or leaching of Nitrogen and Phosphorus. The type of tillage system used also influences where nutrients are found within the soil profile and their vulnerability to loss. Systems utilizing some form of full width tillage allow the incorporation of applied fertilizers and manures, removing some nutrients from the soil surface and placing them away from overland flow which could carry them to surface water. Fertilizers and liquid manures can be injected or otherwise placed below the soil surface in any tillage system, including no - till, protecting them from runoff, but incorporation of dry manures requires some form of tillage.

\subsubsection{Nitrogen}

As nitrate is soluble and quickly moves into the soil with rainfall or irrigation, little nitrate is usually present in surface runoff. Ammonia held on soil particles and organic nitrogen can move off fields with erosion and runoff. Conservation tillage reduces runoff of these forms of nitrogen. A 97\% reduction in soil loss for no- till relative to the moldboard plow resulted in a 75 to $90 \%$ reduction in total $\mathrm{N}$ loss for soybeans following corn and 50 to $73 \%$ reduction in total $\mathrm{N}$ loss for corn following soybeans (Baker and Laflen 1983). Other studies have documented reductions in $\mathrm{N}$ losses with conservation tillage (Seta et al. 1993). Because in most settings nitrate reaches streams by first infiltrating and then moving with subsurface flow, increases in infiltration caused by conservation tillage could impact both nitrate leaching and eventual movement to surface water. Many researchers have investigated the impact of no - till and other conservation tillage systems on nitrate leaching. Most studies have found little impact, with some studies finding a reduction in nitrate leaching with no - till.

\subsubsection{Phosphorus}

Because total P losses in runoff are made up primarily of insoluble $\mathrm{P}$ carried by eroded sediment particles, conservation tillage usually reduces total P losses . Particulate $\mathrm{P}$ often represents 60 to $90 \%$ of the total P load of 
row crop runoff (LSharpley et al. 1992). Conservation tillage has been an important BMP recommended to farmers to reduce P losses in specific watershed projects. For example, following wide-scale promotion of conservation tillage to reduce P loading to the Great Lakes, Baker (1993) concluded that the downward trends in total and soluble P loads from Lake Erie tributaries for the period from the late 1970s to 1993 indicated that agricultural practices, including conservation tillage, were effective in reducing total and soluble $\mathrm{P}$ export. Kimmel et al. (2001) measured P runoff losses as affected by tillage system and fertilizer placement. A chisel plow- field cultivate- disk system was compared to no- till and ridge - till, with P fertilizer either broadcast surface applied or knifed in prior to planting sorghum . Reductions in P losses with knifing were most evident for soluble P. Knifing reduced soluble P losses by about $75 \%$ in no- till, and ridge- till.

Table 3.Tillage and $\mathrm{P}$ placement effects on soluble, bioavailable, and total $\mathrm{P}$ loss in runoff water from sorghum grown on a silt loam soil with 1.0 to $1.5 \%$ slope.

\begin{tabular}{|l|l|l|l|l|}
\hline \multirow{2}{*}{$\begin{array}{l}\text { Tillage } \\
\text { System }\end{array}$} & \multirow{2}{*}{$\begin{array}{l}\text { Fertilizer } \\
\text { Placement }\end{array}$} & Soluble P & Bioavailable P & Total P \\
\hline Chisel - disk & Surface & 16.0 & 49.5 & 605.0 \\
\hline Chisel - disk & Knifed- in & 12.3 & 33.0 & 354.0 \\
\hline No- Till & Surface & 329.0 & 398.5 & 832.5 \\
\hline No- Till & Knifed- in & 73.5 & 123.5 & 479.5 \\
\hline Ridge- Till & Surface & 320.5 & 426.0 & 1122.5 \\
\hline Ridge- Till & Knifed- in & 77.5 & 121.5 & 675.5 \\
\hline
\end{tabular}

Source: Kimmell et al., (2001).

\section{Conservation Tillage effect on Climate Change}

High carbon sequestration has been given as one of the credits of no-tillage (Lal et al., 2007). Conversion from conventional tillage to no-till has been reported to yield a carbon sequestration rate of $367-3667 \mathrm{~kg} \mathrm{CO}_{2} \mathrm{ha}^{-1}$ year $^{-1}$ (Tebrügge \& Epperlein, 2011). Gambolati et al., (2005) observed that conservation tillage practices decreased the exposure of un-mineralized organic substances to the microbial processes, thus reducing SOM decomposition and $\mathrm{CO}_{2}$ emission. Apart from $\mathrm{C}$, other greenhouse gases (GHGs) notably, nitrous oxide $\left(\mathrm{N}_{2} \mathrm{O}\right)$ and methane $\left(\mathrm{NH}_{4}\right)$, have been reported to be influenced by tillage regimes (Parkin and Kasper, 2006). About $38 \%$ of the emissions to the atmosphere can be ascribed to nitrous oxide from soils (Bellarby et al., 2008) while methane is considered as the most potential greenhouse gas after carbon dioxide (IPCC, 2001). Significantly higher $\mathrm{N}_{2} \mathrm{O}$ emissions from ploughed than no-tilled site has been reported by Kessavalou et al. (1998). The higher aeration in tilled soil increases oxygen availability, possibly resulting in increased aerobic turnover in the soil and thus an increased potential for gaseous emissions (Skiba, et al., 2002).

\subsection{Effect on Carbon Dioxide Emissions}

Tillage has a major influence on soil $\mathrm{C}$ emissions and is one of the principal agronomic activities thought to reduce SOC stocks. It was estimated that $100 \%$ conversion to no-tillage could offset all direct fossil fuel-carbon emissions from agriculture (Smith et al., 1998). Reicosky and Archer (2007) reported that the $\mathrm{CO}_{2}$ released immediately following tillage increased with ploughing depth and in every case was substantially greater than that from the no-tillage treatment. Intensive soil cultivation breaks down soil organic matter (SOM), producing $\mathrm{CO}_{2}$, and consequently reduces the total $\mathrm{C}$ content. There are many reports suggesting that soil tillage accelerates organic $\mathrm{C}$ oxidation, releasing large amounts of $\mathrm{CO}_{2}$ to the atmosphere over a few weeks (La Scala et al., 2008). Conservation tillage has been shown to result in a greater percentage of soil present in macro-aggregates and a larger proportion of carbon associated with micro-aggregates compared to that in conventional ploughing (He et al., 2011). Under conventional ploughing, macro-aggregates are readily broken down prior to micro-aggregate formation. This leads to a reduction in the proportion of $\mathrm{C}$ that is more protected in micro-aggregates and thus to the loss of recalcitrant SOC (Six et al., 2002). Conceptual models of aggregate turnover have hypothesized that slower macro-aggregate turnover and the ratio of fine to coarse particulate organic matter within macroaggregates can be used as a relative measure of the turnover of these aggregates (Six et al., 2000). Differences in aggregate stability are very large when CT is compared to soil subjected to mould board ploughing (Martınez et al., 2008), with intermediate values when compared to reduced tillage systems, like chisel tillage (AlvaroFuentes et al., 2008). The improved aggregate stability under CT management results from greater biological activity in these soils (Tisdall and Oades, 1982), and a reduction in the breakdown of surface soil aggregates also results because of protection offered by residues remaining on the soil surface (Zhang et al., 2007).

The potential to reduce atmospheric $\mathrm{CO}_{2}$ through the adoption of Conservation Tillage is therefore quite considerable. A different systems of soil tillage it is possible to conclude that direct drilling (no-tillage) system is characterized by lowest influence on soil and therefore causes lowest $\mathrm{CO}_{2}$ emissions released from soil into the atmosphere (table 3). If direct drilling will be taken as a basis for comparison, then using reduced tillage system will be reflected as escalation by $43.44 \%$ in regards to $\mathrm{CO}_{2}$ emissions released from soil. In comparison with 
systems using conventional ploughs it was increase by $114.39 \%$ which is more than double amount of $\mathrm{CO}_{2}$ emissions and carbon loss from the soil. While in case of difference between reduced tillage and conventional tillage by using mould board plough it was only $49.46 \%$ increase it still means almost a half more $\mathrm{CO}_{2}$ emissions released from soil (Krištof et al.,2014).

Table 4. The effect of soil tillage intensity on carbon dioxide emissions released from soil into the atmosphere, $\mu \mathrm{mol} \mathrm{m} \mathrm{s}^{-1}(\mathrm{n}=60)$.

\begin{tabular}{|c|c|c|c|}
\hline \multirow[t]{2}{*}{ Parameters } & \multicolumn{3}{|c|}{$\mathrm{CO}_{2}$ emissions, $\mu \mathrm{mol} \mathrm{m} \mathrm{m}^{-2} \mathrm{~s}^{-1}$} \\
\hline & No-tillage & Reduced tillage & Ploughing \\
\hline Mean & $2.014^{\mathrm{a}}$ & $2.889^{\mathrm{b}}$ & $4.318^{c}$ \\
\hline Standard deviation & 0.444 & 0.346 & 0.421 \\
\hline Min & 1.150 & 2.310 & 3.180 \\
\hline Max & 2.960 & 3.380 & 4.990 \\
\hline Range & 1.810 & 1.070 & 1.810 \\
\hline CV $(\%)$ & 22.064 & 11.993 & 9.750 \\
\hline
\end{tabular}

Source: Krištof et al., (2014)

Different letters in superscript $\left({ }^{a, b, c}\right)$ mean the effect of the soil tillage intensity on carbon dioxide emissions released from soil into the atmosphere. It indicates that means are significantly different at $\mathrm{P}<0.05$ according to the LSD multiple-range test at the $95.0 \%$ confidence level.

\subsubsection{Carbon Sequestration under conservation tillage}

Carbon in soil and biota forms a major component of global carbon cycle (Lal, 2004), and increasing C sequestration in soil can mitigate increasing atmospheric $\mathrm{CO}_{2}$ concentration (Kimble et al., 2001). A reduction in soil tillage is suggested to increases the rates of carbon sequestration by altering soil physico-chemical and biological conditions (Marland et al., 2004). Conservation tillage is regarded as an important resource management practices that help to sequester as much as 100-1000 kg C ha-1 per year (Lal, 2004). The sequestration of carbon within no-till management occurs faster under humid conditions with Six et al. (2004) reporting sequestration within 5 years under such climatic conditions $\left(194 \mathrm{~kg} \mathrm{C} \mathrm{ha}^{-1} \mathrm{yr}^{-1}\right)$. Example sequestration rates obtained under various conservation tillage studies obtained a mean carbon sequestration rate of $340 \mathrm{~kg} \mathrm{ha}^{-}$ ${ }^{1}$ per year from 76 long term experiments for extending soil depth of up to $30 \mathrm{~cm}$ over 20 years. Similarly, a comparable sequestration of carbon was noticed by Six et al. (2002) in both tropical and temperate soils. The carbon sequestration capabilities increased considerably with an increase in duration under conservation tillage, with the increment more evident under tropical conditions. Our meta-analysis suggests the carbon sequestration rate under conservation tillage of the top $25 \mathrm{~cm}$ soil was $735 \mathrm{~kg} \mathrm{ha}^{-1}$ per year in tropical regions against $165 \mathrm{~kg}$ ha-1 per year in temperate soils $(\mathrm{P}<0.05$ for tropical and $\mathrm{P}<0.001$ for temperate). The changes in carbon sequestration is also dependent on many other variables such as crop rotation, soil type (Gaiser et al., 2009) and soil drainage (Duiker and Lal, 1999). Mc Conkey et al. (2003) noticed a linear relationship with clay content and increase in carbon stock under no-till which was further confirmed by Grace et al. (2012) who recorded more than double the sequestration rate in clay soils compared to sandy soils in India. The ability to sequester carbon also depends on the initial carbon content at the initiation of conservation tillage practices as there is an upper limit of maximum carbon that could be sequestered. Therefore, it is crucial to consider these parameters when evaluating the benefits of any conservation tillage programme.

\subsection{Methane Emissions}

Methane $\left(\mathrm{CH}_{4}\right)$ is one of the main anthropogenic greenhouse gases, which contribution to global warming is estimated in 20\% (IPCC, 2007). Soil $\mathrm{CH}_{4}$ fluxes are a net result of the $\mathrm{CH}_{4}$ production (+) by methanogens and $\mathrm{CH}_{4}$ oxidation (-) by methanotrophy processes (Bags et al., 2006). Usually, undisturbed soils act as a net $\mathrm{CH}_{4}$ sink, but a dramatic decrease on the $\mathrm{CH}_{4}$ oxidation rates is experienced when soils are converted to agriculture, which effect has been mainly related to the soil disturbance and to the ammonium-based $\mathrm{N}$ fertilization (Mojeremane et al., 2011).Most studies indicate an increased absorption of $\mathrm{CH}_{4}$ in soils under no tillage due to reduced surface disruption (Regina and Alakukku, 2010), and due to greater pore continuity with the presence of more micro sites for methanotrophy bacteria (Hütsch, 1998). This increased soil bulk density under conservation tillage might prevent the efflux of $\mathrm{CH}_{4}$ leading to its oxidation within soil (Li et al., 2011).

Long term studies by Ussiri et al. (2009) indicated a net $\mathrm{CH}_{4}$ uptake in no-till silt loam soils under maize. They found an uptake of $0.32 \mathrm{~kg} \mathrm{CH}-\mathrm{C} \mathrm{ha-1} \mathrm{year}^{-1}$ against an emission of $2.76 \mathrm{~kg} \mathrm{CH}_{4}-\mathrm{C} \mathrm{ha}^{-1} \mathrm{year}^{-1}$ in conventional till. Continuous ecological disturbance under tillage can be detrimental to methane oxidizers. Most previous studies indicate conservation tilled soils act as a net sink for methane. However, both increased and decreased $\mathrm{CH}_{4}$ consumption has been reported in no-till soils (Venterea et al., 2005). If a conservation tillage system creates anaerobic micro sites or makes conditions favorable for enhanced water logging conditions, then it is likely $\mathrm{CH}_{4}$ production and therefore emissions will increase. 


\subsection{Nitrous oxide Emissions}

Many workers have reported increased $\mathrm{N}_{2} \mathrm{O}$ emission under no-tillage compared to conventional tillage (Oorts et al., 2007). This has been attributed to decreased water filled pore space, mineral nitrogen concentration (Oorts et al., 2007), reduced gas diffusivity and air-filled porosity (Chatskikh and Olesen, 2007), Increased $\mathrm{N}_{2} \mathrm{O}$ fluxes under conservation tilled soils might be attributed to the increased anaerobic conditions provided by the increased bulk density and decreased soil porosity due to soil consolidation (Ball et al., 1999). The physical characteristics of the soil in different layers, as modified by different tillage practices, affect the flux of $\mathrm{N}_{2} \mathrm{O}$. If $\mathrm{N}_{2} \mathrm{O}$ is produced at surface layers, which are more permeable, the gas is likely to be emitted, but if the point of production is in lower layers, overlaid by compact layers, the $\mathrm{N}_{2} \mathrm{O}$ produced may be consumed within the profile. The adoption of conservation tillage over a long term (20 years) was reported to nullify this adverse effect of $\mathrm{N}_{2} \mathrm{O}$ emissions with lower $\mathrm{N}_{2} \mathrm{O}$ emissions under no-tillage than under tilled soil in humid climates and similar emissions under both tillage types in dry climates (Six et al., 2004). Similar reports were also made by Kessavalou et al. (1998) and Chatskikh et al. (2008) attributable to increased $\mathrm{N}_{2} \mathrm{O}$ consumption in soil (Luo et al., 2010). However the uncertainty associated with estimation of $\mathrm{N}_{2} \mathrm{O}$ remains high in most experiments due to significant spatial and temporal variability (Chatskikh et al., 2008; Ussiri et al., 2009).

\section{Conclussion}

Soil perturbation by conventional tillage makes the soil serve as a source rather than a sink of atmospheric pollutants and thus is not sustainable and environmentally friendly. However, the international development organizations seem to be in favour of promoting conservation agriculture in general rather than no-tillage exclusively.

In fine-textured and poorly drained soils, the use of MT is encouraged while in well-drained soils with light to medium texture and low humus content, the NT seems to be advantageous. Zero or MT is beneficial to soil physical improvement as process of soil physical degradation normally sets in immediately after CT. Research reports indicate that conservation tillage, particularly MT, is better than CT in terms of soil chemical improvement. All available reports are in agreement that soils under conservation tillage are more favoured than CT in terms of soil fauna.

There is emphasis on the importance of transition to NT system on reduction of runoff and maintenance of environmental quality. Also, crop grown with NT has more climate adaptation (e.g. drought and high temperatures) benefits and thereby high yield than those on tilled plots while crops grown on minimum tillage have the benefit of better yield than CT and NT due to breaking of compact layer and moderate soil perturbation.

The potential benefits of conservation tillage along with other practices such as soil cover in reducing carbon and nitrous-oxide emissions to the atmosphere cannot be over emphasized. Therefore, to achieve sustainable food production with minimal impact on the soil and the atmosphere, conservation tillage practices become more important now than ever.

\section{REFERENCES}

Ali, A., Ayuba, S. A., \& Ojeniyi, S. O. 2006. Effect of tillage and fertilizer on soil chemical properties, leaf nutrient content and yield of soyabean in the Guinea savanna zone of Nigeria. Nigerian Journal of Soil Science, 16, 126-130.

Allen Dobb.2013. BC Farm and Climate change adaptation. Agriculture \& Food Climate Action Initiative; British Columbia. Online available at www. BCAgClimateAction.ca.

Allmaras, R. R., Rickman, R. W., Ekin, L. G., \& Kimball, B. A. 1977. Chiselling influences on soil hydraulic properties. Soil Science Society of America Journal, 41, 796-803.

Allmaras, R.R., Dowdy, R.H. 1985. Conservation tillage systems and their adoption in the United States. Soil Till. Res. 5, 197-222.

Alvaro-Fuentes, J., Lopez, M.V., Cantero-Martınez, C. \& Arrue, J.L. 2008. Tillage effects on soil organic carbon fractions in Mediterranean dry-land agro-ecosystems. Soil Science Society of America Journal, 72, 541-547.

Anderson, E. L. 1987. Corn root growth and distribution as influenced by tillage and nitrogen fertilization. Agronomy Journal, 79, 544-549.

Angers, D.A., Eriksen-Hamel, N.S. 2008. Full-inversion tillage and organic carbon distribution in soil profiles: a meta-analysis. Soil Science Society of America Journal 72, 1370-1374.

Anikwe, M. A.N., \& Ubochi, J. N. 2007. Short-term changes in soil properties under tillage systems and their effect on sweet potato (Ipomea batatasL.) growth and yield in an Ultisol in south-eastern Nigeria .Australian Journal of Soil Research, 45, 351-358.

ASAE (American Society of Agricultural and Biological Engineers). 2005. Terminology and definitions for soil tillage and soil-tool relationships. ASAE EP291.3 FEB2005:131-134.

Baker, J. L., J. M. Laflen. 1983. Water quality consequences of conservation tillage. J. Soil Water Conserv. 
38(3): 186-193.

Baker, J.M., Ochsner, T.E., Venterea, R.T., Griffis, T.J. 2007. Tillage and soil carbon sequestration--What do we really know? Agriculture, Ecosystems and Environment 118, 1-5.

Ball, B.C., Scott, A., Parker, J.P. 1999. Field N2O, $\mathrm{CO}_{2}$ and $\mathrm{CH}_{4}$ fluxes in relation to tillage, compaction and soil quality in Scotland. Soil and Tillage Research 53, 29-39.

Bellarby, J., Foereid, B., Hastings, A., Smith, P. 2008.Cool Farming: Climate impacts of agriculture and mitigation potential, Published by Greenpeace International OtthoHeldringstraat 51066 AZ Amsterdam, The Netherlands.

Benjamin, J. G. 1993. Tillage effects on near-surface soil hydraulic properties. Soil and Tillage Research, 26, $277-288$.

Bhatt, R., \& Khera, K. L. 2006. Effect of tillage and mode of straw mulch application on soil erosion in the submontaneous tract of Punjab, India. Soil and Tillage Research, 88, 107-115.

Blanco-Canqui, H., Schlegel, A.J., Heer, W.F. 2011. Soil-profile distribution of carbon and associated properties in no-till along a precipitation gradient in the central Great Plains. Agriculture, Ecosystems \& Environment 144, 107-116.

Busari, M. A., \& Salako, F. K. 2012. Effect of tillage and poultry manure application on soil infiltration rate and maize root growth in a sandy Alfisol. Agro-science. Journal of Tropical Agriculture, Food, Environment and Extension, 11, 24-31.

Busari, M. A., \& Salako, F. K. 2013. Effect of tillage, poultry manure and NPK fertilizer on soil chemical properties and maize yield on an Alfisol at Abeokuta, south-western Nigeria. Nigerian Journal of Soil Science, 23, 206-2 18.

Busari, M.A.,Salako, F.K. 2012. Effect of tillage and poultry manure application on soil infiltration rate and maize root growth in a sandy Alfisol. Agro-science. Journal ofTropical Agriculture, Food, Environment and Extension, 11, 24-31.

Butorac, A. 1994. Conservation tillage in Eastern Europe. In: M. R. Carter (Ed.), Conservation tillage in temperate agro ecosystems(pp. 357-374). Boca Raton: Lewis Publisher.

Chatskikh, D., Olesen, J.E. 2007. Soil tillage enhanced $\mathrm{CO}_{2}$ and $\mathrm{N}_{2} \mathrm{O}$ emissions from loamy sand soil under spring barley. Soil and Tillage Research 97, 5-18.

Chatskikh, D., Olesen, J.E., Hansen, E.M., Elsgaard, L., Petersen, B.M. 2008. Effects of reduced tillage on net greenhouse gas fluxes from loamy sand soil under winter crops in Denmark. Agriculture Ecosystems \& Environment 128, 117-126.

Conservation Tillage Systems and Management (CTSM). 2000. 'MWPS-45. Crop residue management with no-till, ridge-till, mulch -till and strip -till.' $2^{\text {nd }}$ edn. (Midwest Plan Service, Iowa State University: Ames, IA).

Cookson, W. R., Murphy, D. V., \& Roper, M. M. 2008. Characterizing the relationships between soil organic matter components and microbial function and composition along a tillage disturbance gradient. Soil Biology and Biochemistry, 40, 763-777.

Crutzen, P J., Mosier, A R., Smith K A. and Winiwarter W. 2008. $\mathrm{N}_{2} \mathrm{O}$ release from agro bio fuel production negates global warming reduction by replacing fossil fuels. Atmos, Chem, Phys.8:389-395.

Dalal, R. C. 1992. Long-term trends in total nitrogen of a Vertisol subjected in zero tillage, nitrogen application and stubble retention. Australian Journal of Soil Research, 30, 223-231.

Doran, J. W. 1980. Soil microbial and biochemical changes associated with reduced tillage. Soil Sci. Soc. Am. J., 44, 765-771.

Duiker, S. W, Lal, R. 1999. Crop residue and tillage effects on carbon sequestration in aLuvisol in Central Ohio. Soil and Tillage Research 52: 73-81.

Franzluebbers, A.J. 2002. Soil organic matter stratification ratio as an indicator of soil quality.Soil \& Tillage Research, 66,95-106.

Freebairn, D.M, Rattray, D.J. 2007. Tillage and the environment in sub-tropical Australia-tradeoffs and challenges. Soil \& Tillage Research 97, 306-317.

Gaiser, E., Bachmann, R., Battoe, L.,Deyrup, N., Swain, H. 2009. Effects of climate variability on transparency and thermal structure in subtropical, monomictic Lake Annie, Florida. American Society of Limnology and Oceanography, Inc.54(6), 2228-2232.

Gambolati, G., P. Teatini, and M. Ferronato. 2005. Anthropogenic land subsidence, in the Encyclopedia of Hydrological Sciences, vol. 4, edited by M. G. Anderson, chap. 158, pp. 2443-2459.

Goh, K.M. 2004. Carbon sequestration and stabilization in soils: Implications for soil productivity and climate change. In. Soil Science and Plant Nutrition 50, 467-476.

Grace, J.B., Adler, B.A., Seabloom, E. W.2012. Response to Comments on "Productivity Is a Poor Predictor of Plant Species Richness".Science 335, 1441.

H ütsch, B.W., (1998). Tillage and land use effects on methane oxidation rates and their vertical profiles in soil. 
Biology and Fertility of Soils 27, 284-292.

He, J., Li, H., Rasaily, R.G., Wang, Q., Cai, G., Su, Y., Qiao, X. \& Liu, L. 2011. Soil properties and crop yields after 11 years of no tillage farming in wheat-maize cropping system in North China Plain. Soil \& Tillage Research, 113,48-54.

Hermle, S., Anken, T., Leifeld, J., Weisskopf, P. 2008. The effect of the tillage system on soil organic carbon content under moist, cold-temperate conditions. Soil and Tillage Research 98, 94-105.

Hernanz, J.L., Sánchez-Girón, V., Navarrete, L. 2009. Soil carbon sequestration and stratification in a cereal/leguminous crop rotation with three tillage systems in semiarid conditions. Agriculture, Ecosystems and Environment 133, 114-122.

Hill, R.L. 1990. Long-term Conventional And No-tillage Effects On Selected Soil Physical Properties. Soil Science Society of America Journal 54, 161-166.

Hobbs Peter R., Ken Sayre and Raj Gupta. 2007. The role of conservation agriculture in sustainable agriculture Phil. Trans. R. Soc. B (2008) 363, 543-555; doi:10.1098/rstb.2007.2169. ork, NY, USA, IPCC.

Holland, J.M. 2004. The environmental consequences of adopting conservation tillage in Europe: reviewing the evidence. Agriculture, Ecosystems \& Environment, 103, 1-25.

Intergovernmental Panel on Climate Change. 2001. The Third Assessment Report of the Intergovernmental Panel on Climate Change, Marrakech, Morocco, November 7, 2001.

IPCC. 2007. Intergovernmental panel on climatechange 2007 . Synthesis report.

IPCC. 2007. Climate Change 2007: Synthesis Report. Contributions of Working Groups i, ii, and iii to the Fourth Assessment Report of the Intergovernmental Panel on Climate Change. Geneva: IPCC.

IPCC, Geneva Jones, C.A., Basch, G., Baylis, A.D., Bazzoni, D., Bigs, J., Bradbury, R.B., Chaney, K., Deeks, L.K., Field, R., Gomez, J.A., Jones, R.J.A.,Jordan, V., Lane, M.C.G., Leake, A., Livermore, M., Owens, P.N., Ritz, K., Sturny, W.G. \& Thomas, F. 2006. Conservation Agriculture in Europe: An Approach to Sustainable Crop Production by Protecting Soil and Water? SOWAP, Jealott'sHill, Bracknell, UK.

Ismail, L., Blevins, R. L., \& Frye, W. W. 1994. Long-term no-tillage effects on soil properties and continuous corn yields. Soil Science Society of America Journal, 58, 193-198.

Jastrow, J.D., Amonette, J.E., Bailey, V.L. 2007. Mechanisms controlling soil carbon turnover and their potential application for enhancing carbon sequestration. Climatic Change 80, 5-23.

Kargas, G., Kerkides, P., \& Poulovassilis, A. 2012. Infiltration of rain water in semi-arid areas under three land surface treatments. Soil and Tillage Research, 120, 15-24.

Kemper, W. D., Trout, T. J., Segeren, A., \& Bullock, M. 1987. Worms and water. Journal of Soil and Water Conservation, 42, 401-404.

Kessavalou, A., Doran, J.W., Mosier, A.R., Drijber, R.A. 1998. Greenhouse gas fluxes following tillage and wetting in a wheat-fallow cropping system. Journal of Environmental Quality 27, 1105-1116.

Kessavalou, A., Mosier, A., Doran, J., Drijber, R., Lyon, D., \& Heinemeyer, O. 1998. Fluxes of carbon dioxide, nitrous oxide, and methane in grass sod and winter wheat-follow tillage management. Journal of Environmental Quality, 27, 1094-1104.

Ko“ller, K. 2003. Techniques of soil tillage. In: Soil tillage in agroeco-systems (ed. A. El Titi), pp. 1-25. CRC Press, Boca Raton, FL.

La Scala, N., Lopes, A., Spokas, K., Bolonhezi, D., Archer, D.W. \& Reicosky, D.C. 2008. Short-term temporal changes of soil carbon losses after tillage described by a first-order decay model. Soil \& Tillage Research, 99, 108-118.

Lal, R. 1983. No-till farming: Soil and water conservation and management in the humid and sub-humid tropics. IITA Monograph No. 2, Ibadan, Nigeria.

Lal, R. 1997. Long-term tillage and maize monoculture effects on a tropical Alfisol in western Nigeria. I. Crop yield and soil physical properties. Soil and Tillage Research, 42, 145-160.

Lal, R., Mahboubi, A., Fausey, N.1994. Long-term tillage and rotation effects on properties of a central Ohio soil. Soil Science Society of America Journal 58, 517-522.

Li, D., Liu, M., Cheng, Y., Wang, D., Qin, J., Jiao, J., Li, H., Hu, F.2011. Methane emissions from doublerice cropping system under conventional and no tillage in southeast China. Soil and Tillage Research 113, 77-81.

López-Fando, C., Pardo, M.T. 2011. Soil carbon storage and stratification under different tillage systems in a semi-arid region. Soil and Tillage Research 111, 224-230.

Luo, Z., Wang, E., Sun, O.J. 2010. Can no-tillage stimulate carbon sequestration in agricultural soils? A metaanalysis of paired experiments. Agriculture, Ecosystems \& Environment 139, 224-231.

Lybbert T and Sumner D. 2010. Agricultural Technologies for Climate Change Mitigation and Adaptation in Developing Countries: Policy Options for Innovation and Technology Diffusion. ICTSD and International Food \& Agricultural Trade Policy Council, Issue Brief No. 6, Geneva. Available at: www.ictsd.org. 
Martınez, E., Fuentes, J.-P., Silva, P., Valle, S. \& Acevedo, E. 2008. Soil physical properties and wheat root growth as affected by no-tillage and conventional tillage systems in a Mediterranean environment of Chile. Soil \& Tillage Research, 99, 232-244.

Mc Taggart, I.P., Clayton, H. and Smith, K.A. 1994. Nitrous oxide flux from fertilized grassland: strategies for reducing emissions. In Non- $\mathrm{CO}_{2}$ Greenhouse Gases (Ed. J. van Ham, L.J.H.M. Jassen and R.J.Swart), Kluwer, Dordrecht, 421-426.

McVay, K. A., Budde, J. A., Fabrizzi, K., Mikha, M. M., Rice, C. W. Schlegel, A. Jm. 2006. Management effects on soil physical properties in long-term tillage studies in Kansas. Soil Science Society of America Journal, 70, 434-438.

Mojeremane, W., Rees, R.M., Mencuccini, M. 2011. The effects of site preparation practices on carbon dioxide methane and nitrous oxide fluxes from a peaty gley soil. Forestry 19, 1-15.

MWPS (MidWest Plan Service). 2000. Conservation tillage systems and management. 2nd ed. Crop residue management with no-till, ridge-till, mulch-till and strip-till. MWPS-45. Ames: Iowa State University, Midwest Plan Service.

Oorts, K., Merckx, R., Gréhan, E., Labreuche, J., Nicolardot, B. 2007. Determinants of annual fluxes of CO2 and $\mathrm{N} 2 \mathrm{O}$ in long-term no-tillage and conventional tillage systems in northern France. Soil and Tillage Research 95, 133-148.

Pagliai, M., Vignozzi, N., \& Pellegrini, S. 2004. Soil structure and the effect of management practices. Soil and Tillage Research, 79, 13 1-143. Parkin, T. B., \& Kasper, T. C. (2006). Nitrous oxide emissions from cornsoybeans systems in the Midwest. Journal of Environmental Quality, 35, 1496-1506.

Paustian, K., B.A. Babcock, J. Hatfield, R. Lal, B.A. McCarl, S. McLaughlin, A. Mosier, C. Rice, G.P. Prior S. A., per R L., Runion G. G. 2004. Effect of implement on soil CO2 efflux: fall vs. spring tillage // Transaction of ASAE, vol. 47, p. 367-373.

Peigne, J., Ball, B.C., Roger-Estrade, J., David, C. 2007. Is conservation tillage suitable for organic farming? A review. Soil Use and Management 23, 129-144.

Rasmussen, K. J. 1999. Impact of ploughless soil tillage on yield and soil quality: A Scandinavian review. Soil and Tillage Research, 53, 3-14.

Regina, K., Alakukku, L. 2010. Greenhouse gas fluxes in varying soils types under conventional and no-tillage practices. Soil and Tillage Research 109, 144-152.

Reicosky, D. \& Archer, D.W. 2007. Moldboard plows tillage depth and short-term carbon dioxide release. Soil \& Tillage Research, 94, 109-121.

Reicosky, D.C. \& Saxton, K.E. 2007. Reduced Environmental Emissions and Carbon Sequestration. In: BAKER, C.J. et al. 2007. No-Tillage Seeding in Conservation Agriculture. $2^{\text {nd }}$ Edition. FAO, 2007. 257267.

Rhoton, F. E. 2000. Influence of time on soil response to no-till practices. Soil Science Society of America Journal, 64, 700-709. Riley, H.,

Schneider, W.A. and Pushpam Kumar. 2008. Greenhouse gas mitigation through agriculture. Choices 23(1).

Simmons, B.L., Coleman, D.C. 2008. Microbial community response to transition from conventional to conservation tillage in cotton fields. Applied Soil Ecology 40, 518-528.

Six, J., Elliott, E.T. \& Paustian, K. 2000. Soil macro-aggregate turnover and micro-aggregate formation: a mechanism for $\mathrm{C}$ sequestration under no-tillage agriculture. Soil Biology \& Biochemistry, 32, 2099-2103.

Six, J., Feller, C., Denef, K., Ogle, S.M., de Moraes Sa, J.C. \& Albrecht, A. 2002. Soil organic matter, biota and aggregation in temperate and tropical soils-effects of no-tillage. Agronomy, 22,755-775.

Six, J., Ogle, S.M., Breidt, F.J., Conant, R.T., Mosier, A.R., Paustian, K. 2004. The potential to mitigate global warming with no-tillage management is only realized when practised in the long term. Global Change Biology 10, 155-160.

Smith, P. 2004. Carbon sequestration in croplands: the potential in Europe and the global context. Eur.J. Argon. 20, 229-236.

Smith, P., Powlson, D.S., Glendining, M.J. \& Smith, J.U. 1998. Preliminary estimates of the potential for carbon mitigation in European soils through no-till farming. Global Change Biology, 4, 679-685.

Su, Z., Zhang, J., Wu, W., Cai, D., Lv, J. Jiang, G.2007. Effects of conservation tillage practices on winter wheat water-use efficiency and crop yield on the Loess Plateau, China. Agricultural Water Management, 87, 307-314.

Ussiri, D., Lal, R., Jarecki, M.K. 2009. Nitrous oxide and methane emissions from long-term tillage under a continuous corn cropping system in Ohio. Soil and Tillage Research 104, 247-255.

Venterea, R.T., Burger, M., Spokas, K.A. 2005. Nitrogen oxide and methane emissions under varying tillage and fertilizer management. Journal of Environmental Quality 34, 1467-1477.

Zhang, G.S., Chan, K.Y., Oates, A., Heenan, D.P. \& Huang, G.B. 2007. Relationship between soil structure and runoff/soil loss after 24 years of conservation tillage. Soil \& Tillage Research, 92, 122-128. 